\title{
Ceftriaxone: clinical review, consumption in Portugal and safety alerts
}

\author{
Ceftriaxona: revisão clínica, consumo em Portugal e alertas de segurança
}

Carla Pires, Ana Fernandes

CBIOS - Universidade Lusófona's Research Center for Biosciences and Health Technologies, Campo Grande, 376, 1749-

024, Lisboa, Portugal

Email: carla.pires@ulusofona.pt

\begin{abstract}
Ceftriaxone is a $3 \mathrm{rd}$ generation cephalosporin, often prescribed because of its broad spectrum of action. Objectives: (i) To prepare a clinical review of ceftriaxone. (ii) To describe/analyse the profile of cephalosporins consumed in outpatient clinics by Portuguese districts in 2015. (iii) To identify/analyse the safety alerts of ceftriaxone issued by the National and European Medicines (EMA) Agencies. Methods: Diverse sources were accessed, namely PubMed and Micromedex. The report of INFARMED, I.P. on the consumption of cephalosporins in Portugal and the safety alerts of ceftriaxone on the website of INFARMED, I.P. and the EMA were consulted. Results: The clinical review was developed. The districts of Lisbon, Coimbra, Portalegre, Porto and Leiria presented consumptions above the national average (21.25 DHD). Ceftriaxone was the second most commonly used cephalosporin in this group. Only two informative circulars of INFARMED, I.P. on the safety of ceftriaxone were identified. Both circulars were based on the benefit risk assessments of EMA. Conclusion: The efficacy and safety profile of ceftriaxone remains favourable. It is possible that this antibiotic may be prescribed outside the scope of its therapeutic indications, considering the significant differences in its consumption among some Portuguese districts.

Thus, monitoring for the appearance of bacterial resistance is critical.
\end{abstract}

Keywords: ceftriaxone, 3rd generation cephalosporin, antibiotic consumption, safety alerts, pharmacovigilance.

\begin{abstract}
Resumo
A ceftriaxona é uma cefalosporina de $3^{\mathrm{a}}$ geração, frequentemente prescrita devido ao amplo espectro de ação. Objetivos: (i) Elaborar uma revisão clínica da ceftriaxona. (ii) Descrever/analisar o perfil das cefalosporinas consumidas em ambulatório em Portugal por distrito em 2015. (iii) Identificar/analisar os alertas de segurança da ceftriaxona emitidos pelas agências: Nacional e Europeia do medicamento (AEM). Métodos: Foram pesquisadas diversas fontes, nomeadamente PubMed e Micromedex. Consulta do relatório do INFARMED, I.P. sobre o consumo das cefalosporinas em Portugal e dos alertas de segurança da ceftriaxona no site do INFARMED, I.P. e da AEM. Resultados: Elaboração da revisão clínica. Os distritos de Lisboa, Coimbra, Portalegre, Porto e Leiria apresentaram consumos acima da média nacional (21,25 DHD). A ceftriaxona foi a segunda cefalosporina mais consumida neste grupo. Apenas foram identificadas duas circulares informativas de segurança do INFARMED, I.P. sobre a ceftriaxona, que se basearam nas avaliações risco benefício da AEM. Conclusão: O perfil de eficácia e segurança da ceftriaxona mantem-se favorável. É possível que este antibiótico possa estar a ser prescrito fora do âmbito das suas indicações terapêuticas, tendo em conta as diferenças expressivas no seu consumo entre alguns distritos Portugueses. Assim, a vigilância do aparecimento de resistểncias bacterianas é fundamental.
\end{abstract}

Palavras chave: ceftriaxona, cefalosporina de $3^{\mathrm{a}}$ geração, consumo de antibióticos, alertas de segurança, farmacovigilância 


\section{Introduction}

In Portugal, antibiotic consumption was $4.1 \%$ of total use of medicines in hospitals, with cephaloporins accounting for $20.8 \%$ of all antibiotics in $2017 .^{(1)}$ Overall, $80-90 \%$ of the antibiotic prescriptions are from primary health care units for the treatment of respiratory infections. ${ }^{(2)}$ In 2015, ceftriaxone was the second most used $3^{\text {rd }}$ generation cephalosporin in Portugal, with cefixime occupying the first place. ${ }^{(3)}$ Ceftriaxone is a $3^{\text {rd }}$ generation cephalosporin comparable in its spectrum of antimicrobial action to cefotaxime and ceftizoxime. ${ }^{(4,5)}$ It is an antibiotic with a well-known efficacy and safety profile. It is estimated that since its approval in 1985, Ceftriaxone has been administered to more than 100 million people worldwide. ${ }^{(6)}$ Ceftriaxone's broad spectrum of antimicrobial action and good systemic tolerance, associated with a long plasma half-life, represents the main advantage of ceftriaxone compared to the remaining third-generation cephalosporins. ${ }^{(1-6)}$

Ceftriaxone has a good activity against gram-negative microorganisms and a reasonable activity against grampositive microorganisms. In clinical practice, ceftriaxone is used to treat diverse infections, including bone and knee, gonorrhea, or intra-abdominal. In addition, this antibiotic is primarily indicated for the treatment of bacterial meningitis against gram-negative microbial agents and resistant infections caused by Enterobacteriaceae. Particularly, it is possible to avoid the use of aminoglycosides due the good diffusion of ceftriaxone in the CNS. For instance, two hours after of administering $100 \mathrm{mg} / \mathrm{kg}$ of ceftriaxone in patients with bacterial meningitis, a therapeutic concentration in the cerebrospinal fluid is achieved $(20 \mathrm{mcg} / \mathrm{ml})$. Ceftriaxone is the drug of choice in the treatment of indole-positive Proteus infections (e.g., urinary infections) and complicated and uncomplicated gonococcal infections in adults and children. Ceftriaxone may be particularly useful in hospitalized patients, since longer administration times are preferred, or in outpatients receiving parenteral therapy. ${ }^{(7,8)}$

Objectives: (i) To carry out a clinical review of ceftriaxone based on the following sources: summary of antibacterial activity, resistance, therapeutic indications, including comparative efficacy with other cephalosporins, combination with other antibiotics, dose, overdose, pharmacokinetics, adverse reactions, contraindications and precautions. (ii) To describe and analyze the profile of cephalosporins administered in community in Portugal by district in the year 2015. (iii) To identify and analyze the safety alerts of ceftriaxone issued by the National and European Medicines Agencies.

\section{Introdução}

Em Portugal, o consumo de antibióticos foi de 4,1\% do total da utilização hospitalar de medicamentos, com as cefaloporinas a representarem $20,8 \%$ no total desses antibióticos em 2017.(1) É importante destacar que, 80$90 \%$ das prescrições de antibióticos são provenientes de unidades de saúde primárias para o tratamento de infeções respiratórias. ${ }^{(2)}$ No ano de 2015 em ambulatório, a ceftriaxona foi a segunda cefalosporina de $3^{\text {a }}$ geração mais utilizada em Portugal, ocupando o primeiro lugar a cefixima. ${ }^{(3)}$ A ceftriaxona é uma cefalosporina de $3^{\mathrm{a}}$ geração comparável em termos de espectro de ação antimicrobiano à cefotaxima e ceftizoxima. ${ }^{(4,5)}$ Trata-se de um antibiótico com um perfil de eficácia e segurança bastante conhecido e calcula-se que desde a sua aprovação em 1985, já tenha sido administrada a mais de 100 milhões de pessoas a nível mundial. ${ }^{\left({ }^{6}\right)} \mathrm{O}$ largo espectro de ação antimicrobiano e uma boa tolerância sistémica, associadas a uma semivida plasmática longa representa a principal vantagem da ceftriaxona comparativamente às restantes cefalosporinas de terceira geração no tratamento de determinadas infeções. ${ }^{(1-6)}$

A ceftriaxona tem uma boa atividade contra micro-organismos gram-negativos e uma atividade razoável contra os gram-positivos. Na prática clínica a ceftriaxona é utilizada para tratar infeções diversas, nomeadamente infeções dos ossos e joelhos, gonorreia ou intra-abdominais. Além disso, é primariamente indicada no tratamento da meningite bacteriana contra agentes microbianos gram-negativos e infeções resistentes causadas por Enterobacteriaceae. A sua utilização permite evitar a utilização dos aminoglicosídeos, por ter boa difusão no SNC. Por exemplo, 2 h após a administração de $100 \mathrm{mg} / \mathrm{kg}$ em doentes com meningite bacteriana é atingida uma concentração terapêutica de ceftriaxona no fluído cerebrospinal $(20 \mathrm{mcg} / \mathrm{mL})$. A ceftriaxona é o medicamento de escolha no tratamento de infeções Proteus indol positivas (ex. infeções urinárias) e em infeções gonococcicas complicadas e não complicadas em adultos e crianças. A ceftriaxona pode ser particularmente útil em doentes hospitalizados onde são preferidos tempos de administração mais longos ou nos doentes em ambulatório a fazer terapia parenteral. ${ }^{(7,8)}$

Objetivos: (i) Revisão clínica da ceftriaxona com base em fontes bibliográficas: compilação da atividade antibacteriana, resistências, indicações terapêuticas, incluindo a eficácia comparativa com outras cefalosporinas, combinação com outros antibióticos, dose, sobredosagem, farmacocinética, reações adversas, contraindicações e precauções. (ii) Descrever e analisar o perfil das cefalosporinas consumidas em ambulatório 
Methods: (i) The bibliographic sources were, as follows: the American Hospital Formulary, ${ }^{(9)}$ the Pharmacological Basis of Therapeutics, ${ }^{(10)}$ and Martindale. ${ }^{(11)}$ In addition, articles from the Micromedex and PubMed were conveniently selected, as well as summaries of product characteristics of ceftriaxone recently updated; these documents were used to complement information. (ii) In 2015, the consumption of cephalosporins in community per district in Portugal was consulted in the report of INFARMED, I.P. on consumption of antibiotics. ${ }^{(3)}$ Intakes of cephalosporins were expressed in the daily dose defined per 1000 inhabitants per day (DHD), as recommended by the World Health Organization (WHO). DHD indicates the proportion of the population receiving a certain medicine on a given daily dose. (iii) Safety warnings on ceftriaxone without temporal limitations were collected from the site of INFARMED, I.P. and the European Medicine Agency.

\section{Results}

\section{Clinical review of ceftriaxone}

Ceftriaxone is a third-generation cephalosporin, administered IM or IV. ${ }^{(4,9-12)}$ Ceftriaxone is a semi synthetic antibiotic, which empirical formula is $\mathrm{C}_{18} \mathrm{H}_{16} \mathrm{~N}$ ${ }_{8} \mathrm{Na}_{2} \mathrm{O}_{7} \mathrm{~S}_{3}$. Its chemical structure is represented in Figure 1. ${ }^{(9-12)}$ em Portugal por distrito no ano de 2015. (iii) Identificar e analisar os alertas de segurança da ceftriaxona emitidos pelas agências: Nacional e Europeia do medicamento.

Métodos: (i) Foram utilizadas como fontes bibliográficas: o Formulário Hospitalar Americano, ${ }^{(9)}$ as Bases Farmacológicas da Terapêutica ${ }^{(10)}$ e o Martindale. ${ }^{(11)}$ Adicionalmente, foram selecionados por conveniência artigos da base de dados Micromedex, e da PubMed, e Resumos de Características de Medicamentos com ceftriaxona recentemente atualizados. (ii) $\mathrm{O}$ consumo das cefalosporinas em ambulatório por distrito foi extraído do relatório do INFARMED, I.P. sobre o consumo de antibióticos em Portugal no ano de 2015. ${ }^{(3)}$ Estes consumos encontram-se expressos na dose diária definida por 1000 habitantes por dia (DHD) conforme recomendado pela Organização Mundial de Saúde (OMS). A DHD indica a proporção da população que diariamente recebe o tratamento com determinado medicamento numa determinada dose média. (iii) Os alertas de segurança da ceftriaxona foram recolhidos do site do INFARMED, I.P. e da Agência Europeia do Medicamento sem limitações temporais.

\section{Resultados}

\section{Revisão clínica da ceftriaxona}

A ceftriaxona é uma cefalosporina de terceira geração, administrada por via IM ou IV. ${ }^{(4,9-12)}$ A ceftriaxona é um antibiótico semissintético, cuja fórmula empírica é $\mathrm{C}_{18} \mathrm{H}_{16} \mathrm{~N}_{8} \mathrm{Na}_{2} \mathrm{O}_{7} \mathrm{~S}_{3}$. A sua estrutura química é representada na Figura 1. ${ }^{(9-12)}$

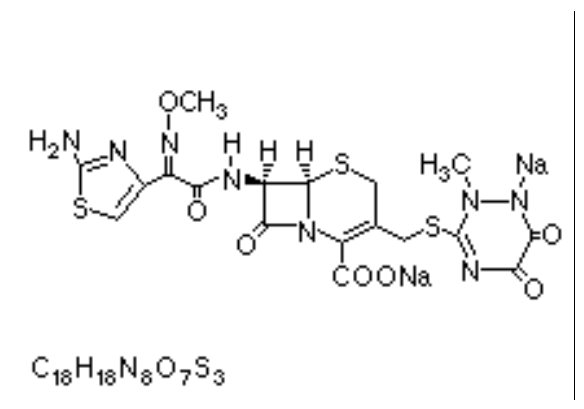

Figure 1/ Figura 1 - Chemical structure of ceftriaxone/ Estrutura química da ceftriaxona 


\section{Antibacterial activity}

Cephalosporins inhibit bacterial cell wall synthesis by a similar mechanism to penicillin. ${ }^{(10)}$ Ceftriaxone is a third-generation cephalosporin administered IM or IV with bactericidal activity. Ceftriaxone binds to penicillin binding proteins (PLPs) within the bacterial wall resulting in the inhibition of transpeptidation of the glycopeptide polymers, which constitutes the final stage of bacterial cell wall synthesis. The result is the formation of a bacterial wall that is osmotically unstable. These events may be associated with the activation of autolytic enzymes in susceptible bacteria, resulting in lysis of the bacterial wall. Ceftriaxone affinity for PLPs is increased in comparison to the first and second generation cephalosporins. The antimicrobial spectrum of ceftriaxone is related to its affinity pattern for PLPs in different bacterial species. ${ }^{(4,11,13-14)}$

\section{Gram-positive aerobic bacteria}

Ceftriaxone has in vitro activity against most gram positive or non-penicillin-producing (PNP) aerobic cocci from Staphylococcus aureus, Staphylococcus epidermitis, Streptococcus pneumoniae, Streptococcus group A hemolytic (Streptococcus pyogenes) and group B (Streptococcus agalactiae), Streptococcus viridans and group D Streptococci (non-enteroccus). ${ }^{(4,11,13-14)}$

\section{Gram-negative aerobic bacteria}

Ceftriaxone has in vitro activity against the following gram-negative aerobic bacteria: Neisseria meningitidis and most $N$. gonorrhoeae PNP species, with chromosome-mediated resistance (e.g. penicillin) or plasmid-mediated resistance, (e.g. tetracyclines), Haemophilus PNP, Haemophilus influenzae, Haemophilus vparainfluenzae and Haemophilus ducreyi, Enterobacteriacea (Citrobacter diversus, Citrobacter freundii, Enterobacter cloacae, E. aerogenes, Escherichia coli, Klebsiella pneumoniae, Morganella morganii - Proteus morgani, Proteus mirabilis, Proteus vulgaris, Providencia rettgeri - Proteus Rettgeri, Providencia stuartii, Serratia marcescens, Salmonella, Shigella and Yersinia enterocolitica), Pseudomonas aeruginosa sensitive, Pseudomonas acidovorans, Pseudomonas cepacia, Pseudomonas paucimobilis, seudomonas stutzeri, Acinetobacter (Acinetobacter calcoaceticus variety anitratus and Acinetobacter calcoaceticus variety lwoffi), Eikenella corrodens and Moraxella corrodens. ${ }^{(9,15-16)}$
Atividade antibacteriana

As cefalosporinas inibem a síntese da parede celular bacteriana por um mecanismo semelhante ao das penicilinas. ${ }^{(10)}$ A ceftriaxona é uma cefalosporina de terceira geração administrada por via IM ou IV com atividade bactericida. A ceftriaxona liga-se às proteínas de ligação às penicilinas (PLPs) no interior da parede bacteriana resultando na inibição da transpeptidação dos polímeros glicopeptídeos, o que constitui a fase final da síntese da parede celular bacteriana. O resultado é a formação de uma parede bacteriana que é osmoticamente instável. Estes acontecimentos podem estar associados à ativação de enzimas autolíticas em bactérias suscetíveis resultando na lise da parede bacteriana. Na ceftriaxona a afinidade pelas PLPs está aumentada relativamente às cefalosporinas de primeira e segunda geração. O padrão de afinidade da ceftriaxona para as PLPs nas diferentes espécies bacterianas relaciona-se com o seu espectro anti-microbiano. ${ }^{(4,11,13-14)}$

\section{Bactérias aeróbias gram-positivas}

A ceftriaxona tem atividade in vitro contra a maioria dos cocos aeróbios gram positivos produtores ou não produtores de penicilases (PNP) de Staphylococcus aureus, Staphylococcus epidermitis, Streptococcus pneumoniae, Streptococcus do grupo A $\beta$ hemolítico (Streptococcus pyogenes) e do grupo B (Streptococcus agalactiae), Streptococcus viridans e Streptococcus do grupo D (não enteroccus). ${ }^{(4,11,13-14)}$

\section{Bactérias aeróbias gram-negativas}

A ceftriaxona tem atividade in vitro contra as seguintes bactérias aeróbias gram negativas: Neisseria meningitidis e a maioria das espécies de $N$. gonorrhoeae PNP, com resistência mediada por cromossomas (e.g. penicilina) ou por resistência mediada por plasmídeos (e.g. tetraciclinas), Haemophilus PNP, Haemophilus influenzae, Haemophilus parainfluenzae e Haemophilus ducreyi, Enterobacteriacea (Citrobacter diversus, Citrobacter freundii, Enterobacter cloacae, Enterobacter aerogenes, Escherichia coli, Klebsiella Pneumoniae, Morganella morganii - Proteus morgani, Proteus mirabilis, Proteus vulgaris, Providencia rettgeri - Proteus rettgeri, Providencia stuartii, Serratia marcescens, Salmonella, Shigella e Yersinia enterocolitica), Pseudomonas aeruginosa sensiveis, Pseudomonas acidovorans, Pseudomonas cepacia, Pseudomonas paucimobilis, Pseudomonas stutzeri, Acinetobacter (Acinetobacter calcoaceticus variedade anitratus e Acinetobacter calcoaceticus variedade lwoffi), Eikenella corrodens e Moraxella corrodens. ${ }^{(9,15-16)}$ 


\section{Anaerobic bacteria}

Ceftriaxone has in vitro activity against some species of gram-positive anaerobic bacteria: Actinomyces, $\mathrm{Fu}$ sobacterium, Lactobacillus, Peptococcus, Peptostreptococcus, Propionibacterium, Veillonela, Clostridium perfringens, as well as some species of gram-negative anaerobic bacteria: Bacteroides melaninogenicus. ${ }^{(15-16)}$

\section{Spirochetes}

Ceftriaxone has some activity against Treponema pallidum (causal agent of syphilis). Borrelia burgdorferi (causal agent of Lyme disease) is inhibited in vitro by ceftriaxone concentrations of $0.1-1 \mathrm{mcg} / \mathrm{ml}$. $^{(9,15-16)}$

\section{Chlamydia}

Some species of Chlamydia trachomatis are inhibited in vitro by ceftriaxone concentrations of $8-32 \mathrm{mcg} / \mathrm{ml}$. ${ }^{(9,15)}$ However, ceftriaxone is normally considered inactive against Chlamydia trachomatis. ${ }^{(9,15-16)}$

\section{Resistances}

Resistance mechanisms during treatment with ceftriaxone are related to bacterial chromosome-mediated production of $\beta$-lactamases (e.g. Enterobacter and Pseudomonas aeruginosa), non-specific PLP (e.g. Streptococcus pneumoniae), permeability factors, reduced affinity of penicillin binding proteins for ceftriaxone, and bacterial efflux pumps. ${ }^{(9)}$ Ceftriaxone is generally resistant to hydrolysis by $\beta$-lactamases classified as II, III and V according to the Richmond-Sykes classification, some of the PSE type, and most produced by Neisseria gonorrhoeae, Haemophilus influenzae and Staphylococcus. ${ }^{(9,17)}$ The possibility of resistance to gram-positive, gram-negative and anaerobic aerobic bacteria includes the following:

\section{Gram-positive aerobic bacteria}

Enterococcus such as Enterococcus faecalis (Streptococcus faecalis), Streptococcus pneumoniae species with minimum inhibitory concentration (MIC) of 0.5 $\mathrm{mcg} / \mathrm{ml}$ or higher are generally resistant to ceftriaxone and methicillin-resistant Staphylococcus aureus. Some species of Listeria monocytogenes are inhibited in vitro by ceftriaxone concentrations of $0.8-32 \mathrm{mcg} / \mathrm{ml}$, however, most species are considered resistant. ${ }^{(4,9-11,16)}$
Bactérias anaeróbias

A ceftriaxona tem atividade in vitro contra algumas espécies de bactérias anaeróbias gram-positivas: Actinomyces, Fusobacterium, Lactobacillus, Peptococcus, Peptostreptococcus, Propionibacterium, Veillonela, Clostridium perfringens, bem como algumas espécies de bactérias anaeróbias gram-negativas: Bacteroides melaninogenicus. ${ }^{(15-16)}$

\section{Espiroquetas}

A ceftriaxona tem alguma atividade contra o Treponema pallidum (agente causal da sífilis). A Borrelia burgdorferi (agente causal da doença de Lyme) é inibida in vitro por concentrações de $0,1-1 \mathrm{mcg} / \mathrm{ml}$ de ceftriaxona. $(9,15-16)$

\section{Chlamydia}

Algumas espécies de Chlamydia trachomatis são inibidas in vitro por concentrações de $8-32 \mathrm{mcg} / \mathrm{ml}$ de ceftriaxona. ${ }^{(9,15)}$ Embora a ceftriaxona seja normalmente considerada inativa contra a Chlamydia trachomatis. ${ }^{(9,}$ 15-16)

\section{Resistências}

Os mecanismos do aparecimento de resistências durante o tratamento com a ceftriaxona estão relacionados com a produção mediada por cromossomas bacterianos de $\beta$ lactamases (ex. Enterobacter e Pseudomonas aeruginosa), PLP não específicas (ex. Streptococcus pneumoniae), fatores de permeabilidade, reduzida afinidade das proteínas de ligação à penicilina para a ceftriaxona, bombas de efluxo bacterianas. ${ }^{(9)}$ A ceftriaxona é geralmente resistente à hidrólise pelas $\beta$ lactamases classificadas como II, III e V segundo a classificação de Richmond-Sykes, algumas das do tipo PSE e a maioria das produzidas pela Neisseria gonorrhoeae, Haemophilus influenzae e Staphylococcus. ${ }^{(9,17)}$ A seguir descrevem-se a possibilidade de resistências para as bactérias aeróbias gram-positivas, gram-negativas e anaeróbias:

Bactérias aeróbias gram-positivas

Enterococcus como o Enterococcus faecalis (Streptococcus faecalis), espécies de Streptococcus pneumoniae com concentração mínima inibitória (MIC) de 0,5 $\mathrm{mcg} / \mathrm{ml}$ ou superior são geralmente resistentes à ceftriaxona e Staphylococcus aureus meticilino resistentes. Embora algumas espécies de Listeria monocytogenes sejam inibidas in vitro por concentrações de ceftriaxona de $0,8-32 \mathrm{mcg} / \mathrm{ml}$ a maioria das espécies são consideradas resistentes. ${ }^{(4,9-11,16)}$ 


\section{Gram-negative aerobic bacteria}

Strains of Neisseria gonorrhoeae with MIC of 0.25 $\mathrm{mcg} / \mathrm{ml}$ or less are considered sensitive. Although some strains of Pseudomonas aeruginosa are sensitive $\left(\mathrm{MIC}_{90} 16\right.$ to $32 \mathrm{mcg} / \mathrm{ml}$ ), other strains require concentrations greater than $64 \mathrm{mcg} / \mathrm{ml}$ to be inhibited in vitro, and consequently these strains are considered resistant. Pseudomonas fluorescens, Pseudomonas maltophilia and Pseudomonas putida are generally resistant. According the data of some in vitro studies, Citrobacter, Enterobacter, Morganella, Proteus and Pseudomonas can produce $\beta$ lactamases capable of inhibiting the antibiotics. ${ }^{(9-11,16)}$

\section{Anaerobic bacteria}

Gram-positive anaerobic bacteria, such as Clostridium difficile and gram-negative anaerobic bacteria, such as Bacteroides fragilis, Bacteroides distasonis, Bacteroides ovatus, Bacteroides thetaiotaomicron and Bacteroides vulgatus are generally resistant. The findings of in vitro studies showed that Bacteroides can produce $\beta$ lactamases capable of inhibiting the antibiotic. ${ }^{(4,9-11)}$

\section{Therapeutic indications}

Ceftriaxone is used to treat bone and knee infections, gonorrhea, intra-abdominal infections (peritonitis or other infections of the biliary and gastrointestinal tract), pneumonia and other lower respiratory tract infections, meningitis, otitis media, pelvic inflammatory disease, indole positive proteolytic infections, septicemia, surgical prophylaxis and urinary tract infections in clinical practice. ${ }^{(4,9-11,16)}$

\section{Comparative efficacy}

Ceftriaxone has a comparable spectrum of action to cefotaxime. It is more potent than cefoperazone, cefamandole, and ticarcillin in the inhibition of Enterobacteriaceae (Escherichia coli, Klebsiella pneumoniae, Proteus mirabilis, Proteus indole positives and Serratia marcescens). ${ }^{(4,11,16,18)}$ Ceftriaxone is generally less active in vitro against susceptible Pseudomonas aeruginosa strains than cefoperazone, cefsulodin, ceftazidime and broad-spectrum penicillins (e.g. piperacillin).

(4) Like other recent $\beta$ lactam antibiotics, ceftriaxone has a reduced in vitro activity against Staphylococcus compared to cloxacillin, vancomycin, and older cephalosporins, such as cephalothin and cefamandole. ${ }^{(8)} \mathrm{Cef}-$ triaxone is generally as stable as cefotaxime against $\beta$ lactamase inhibition but is less stable than cefoxitin. ${ }^{(9)}$
Bactérias aeróbias gram-negativas

Consideram-se sensíveis estirpes de Neisseria gonorrhoeae com MIC de 0,25 mcg/ml ou inferiores. Embora existam estirpes sensíveis de Pseudomonas aeruginosa $\left(\mathrm{MIC}_{90} 16\right.$ a $\left.32 \mathrm{mcg} / \mathrm{ml}\right)$, outras estirpes requerem concentrações superiores a $64 \mathrm{mcg} / \mathrm{ml}$ para serem inibidas in vitro, motivo pelo qual são consideradas resistentes. São geralmente resistentes a Pseudomonas fluorescens, Pseudomonas maltophilia e Pseudomonas putida. Existem estudos in vitro que demonstram que o Citrobacter, Enterobacter, Morganella, Proteus e Pseudomonas podem produzir $\beta$ lactamases capazes de inibir o antibiótico. ${ }^{(9-11,16)}$

\section{Bactérias anaeróbias}

São geralmente resistentes bactérias anaeróbias gram positivas como o Clostridium difficile e bactérias anaeróbias gram negativas como o Bacteroides fragilis, Bacteroides distasonis, Bacteroides ovatus, Bacteroides thetaiotaomicron e Bacteroides vulgatus. Os resultados de estudos in vitro demonstram que os Bacteroides podem produzir $\beta$ lactamases capazes de inibir o antibiótico. ${ }^{(4,9-11)}$

\section{Indicações terapêuticas}

Na prática clínica é utilizada para tratar infeções dos ossos e joelhos, gonorreia, infeções intra-abdominais (peritonite ou outras infeções das vias biliares e do trato gastrintestinal), pneumonia e outras infeções do aparelho respiratório inferior, meningite, otite média, doença inflamatória pélvica, infeções proteus indol positivas, septicémia, profilaxia cirúrgica e infeções do trato urinário. ${ }^{(4,9-11,16)}$

\section{Eficácia comparativa}

A ceftriaxona apresenta um espectro de ação comparável cefotaxima. É mais potente que a cefoperazona, cefamandole e ticarcilina na inibição das Enterobacteriaceae (Escherichia coli, Klebsiella pneumoniae, Proteus mirabilis, Proteus indol positivos e Serratia marcescens). ${ }^{(4,11,16,18)}$ A ceftriaxona é geralmente menos activa in vitro contra estirpes de Pseudomonas aeruginosa suscetíveis que a cefoperazona, cefsulodina, ceftazidima e penicilinas de largo espectro (ex. piperacilina). ${ }^{(4)}$ À semelhança de outros antibióticos $\beta$ lactâmicos recentes a Ceftriaxona tem uma atividade in vitro mais reduzida contra os Staphylococus comparativamente à cloxacilina, vancomicina e às cefalosporinas mais antigas como a cefalotina e o cefamandole. ${ }^{(8)}$ A ceftriaxona é geralmente tão estável como a cefotaxima contra a inibição pelas $\beta$ lactamases mas é menos estável que a cefoxitina. ${ }^{(9)}$ 
Combination with other antibiotics: Aminoglycosides and other anti-infective

In vitro studies have shown synergistic or additive effects of the combination of ceftriaxone and aminoglycosides (amikacin, gentamicin and tobramycin) against some Enterobacteriaceae, Pseudomonas aeruginosa and Acinetobacter species. The clinical importance of this association is not determined, although some authors defend its use in severe nosocomial infections. Rare cases of antagonism are described. Microorganisms resistant to both antibiotics are not likely to be synergistically inhibited by their association. Studies in rabbits with meningitis have shown that the combination of ceftriaxone with trovafloxacin is synergistic against resistant penicillin Pneumococcus with an increase of about 1.85 -fold relative to the bactericidal activity of the isolated antibiotics. ${ }^{(9,15,19-23)}$

\section{Pharmacokinetics: absorption, distribution, metabolization and elimination}

Plasma and urine concentration of ceftriaxone may be determined by a high-performance liquid chromatography method, according to Trautmann and Haefelfinger. ${ }^{(21,24)}$ Ceftriaxone has a non-linear dose-dependent pharmacokinetics, since binding to plasma proteins is variable from 85 to $95 \%$ with the plasmatic antibiotic concentration. ${ }^{(12)}$

\section{Absorption and plasma concentrations}

Ceftriaxone is administered in the form of sodium salt. Via IM, ceftriaxone has a bioavailability of $100 \%$. ${ }^{(6,}$ 23) The time taken to obtain maximal concentration (Cmax) is 1 to 3 hours (h) for IM (Cmax is $38 \mathrm{mcg} /$ $\mathrm{ml}$ and $95 \mathrm{mcg} / \mathrm{ml}$ following IM administration of 500 $\mathrm{mg}$ and $1 \mathrm{~g}$ of ceftriaxone, respectively) and 30 minutes (min) for IV (concentrations of 82, 151 and $257 \mathrm{mcg} /$ $\mathrm{ml}$ following IV administration of 0.5 and $1 \mathrm{~g}$ of ceftriaxone, respectively). In Table 1 are the mean serum concentrations following administration of ceftriaxone IM/IV for doses of 0.5 to $1 \mathrm{~g} \mathrm{IM/IV.}{ }^{(4,6,9,22-24)}$
Combinação com outros antibióticos: Aminoglicosídeos e outros anti-infecciosos

Estudos in vitro demonstraram efeito sinérgico ou aditivo da combinação entre a ceftriaxona e os aminoglicosídeos (amicacina, gentamicina e tobramicina) contra algumas espécies de Enterobacteriaceae, Pseudomonas aeruginosa e Acinetobacter. A importância clínica desta associação não está determinada, embora alguns autores defendam a sua utilização em infeções nosocomiais graves. Estão descritos casos raros de antagonismo. Não é provável que microrganismos resistentes a ambos os antibióticos sejam sinergicamente inibidos pela sua associação. Estudos em coelhos com meningite demonstram que a associação da ceftriaxona com trovafloxacina é sinérgica contra Pneumococcus penicilino resistentes verificando-se um aumento de cerca de 1,85 vezes relativamente à atividade bactericida dos antibióticos isolados. ${ }^{(9,15,19-23)}$

Farmacocinética: absorção, distribuição, metabolização e eliminação

A concentração da ceftriaxona no plasma e na urina pode ser determinada pelo método da cromatografia líquida de alta eficiência, segundo Trautmann and Haefelfinger. ${ }^{(21,24)}$ A ceftriaxona tem uma farmacocinética dose dependente não linear, pois a ligação às proteínas plasmáticas é variável de 85 a $95 \%$ com a concentração plasmática do antibiótico. ${ }^{(12)}$

Absorção e concentrações plasmáticas

A administração da ceftriaxona é feita sob a forma de sal sódico. Por via IM a ceftriaxona tem uma biodisponibilidade de $100 \%$. $^{(6,23)} \mathrm{O}$ tempo necessário para obter a concentração máxima (Cmax) é de 1 a 3 horas (h) no caso da via IM (Cmax é de $38 \mathrm{mcg} / \mathrm{ml}$ e de $95 \mathrm{mcg} / \mathrm{ml}$ após administração IM de $500 \mathrm{mg}$ e de $1 \mathrm{~g}$ de ceftriaxona respectivamente) e de 30 minutos (min) no caso da via IV (concentrações de 82, 151 e $257 \mathrm{mcg} / \mathrm{ml}$ após a administração por via IV de $0,5,1$ e $2 \mathrm{~g}$ de ceftriaxona respectivamente). A média das concentrações séricas após administração de ceftriaxona IM/IV em doses de 0,5 a $1 \mathrm{~g}$ IM/IV é dada na tabela $1{ }^{(4,6,9,22-24)}$ 
Table 1/ Tabela 1 - Ceftriaxone serum concentration $(\mathrm{mcg} / \mathrm{ml})^{(9,24) / \text { Concentração }}$ sérica da Ceftriaxona ${ }^{(9,24)}$

\begin{tabular}{lllll}
\hline Dosage/ & $\mathbf{0 . 5} \mathbf{h}$ & $\mathbf{1 ~ h}$ & $\mathbf{1 2} \mathbf{h}$ & $\mathbf{2 4} \mathbf{~ h}$ \\
Dose & & & & \\
\hline $\mathbf{0 . 5}$ g IM & 22 & 33 & 16 & 5 \\
$\mathbf{1} \mathbf{g ~ I M}$ & 43.7 & 62.3 & 35.5 & 7.8 \\
$\mathbf{0 . 5}$ g IV & $69-102$ & $51-74$ & $10-21$ & $3-8$ \\
$\mathbf{1}$ g IV & $123.2-150.7$ & $109.5-111$ & $20.2-28.1$ & $4.6-9.3$
\end{tabular}

\section{Distribution}

Area under the curve (AUC) in patients with normal renal function is $551 \pm 91 \mathrm{mcg} \times \mathrm{h} / \mathrm{ml}(500 \mathrm{mg} \mathrm{IV}), 1006$ $\pm 118 \mathrm{mcg} . \mathrm{h} / \mathrm{ml}(1 \mathrm{~g} \mathrm{IV})$, and $1703 \pm 203 \mathrm{mcg} . \mathrm{h} / \mathrm{ml} \mathrm{(2}$ g IV). ${ }^{(24)}$ Ceftriaxone has a plasma protein binding of $83 \%$ to $96 \%$, which is variable with concentration. ${ }^{(4,}$ $6,9,22-29)$

This cephalosporin is distributed in: synovial fluid (mean of $14 \mathrm{mg} / \mathrm{L}$ after $1 \mathrm{~g}$ IV at 24 hours) and peritoneal (mean of 15.3 to $20.1 \mathrm{mcg} / \mathrm{ml}$ after $1 \mathrm{~g} \mathrm{IM}$ at 12 hours), saliva and respiratory tract mucus (mean 1.54 to $2.16 \mathrm{mcg} / \mathrm{ml}$ after $1 \mathrm{~g} \mathrm{IM} /$ day for 7 days), bronchial tissue (mean $11.2 \pm 5.7 \mathrm{mcg} / \mathrm{ml}$ after $1 \mathrm{~g}$ IV at 12 hours), aqueous humor (median $2.27 \mathrm{mcg} / \mathrm{ml}$ after $2 \mathrm{~g}$ IV at 2 hours), cerebrospinal fluid (mean $20 \mathrm{mcg} / \mathrm{ml}$ after $100 \mathrm{mg} / \mathrm{kg}$ at 2 hours), hepatic tissue (mean $130 \mathrm{mg} /$ $\mathrm{kg}$ after $1 \mathrm{~g}$ IV at 12 hours), pulmonary and bronchial inflammation (mean $31.8 \mathrm{mcg} / \mathrm{ml}$ after $2 \mathrm{~g}$ IV at 1 to 2 hours), middle ear (mean $35 \mathrm{mcg} / \mathrm{ml}$ after $50 \mathrm{mg} / \mathrm{kg}$ at 24.3 hours), placenta (mean 19.6 to $40.6 \mathrm{mcg} / \mathrm{ml}$ ) and prostate gland (mean 1 to $50 \mathrm{mcg} / \mathrm{ml}$ after $2 \mathrm{~g}$ IV at 4 hours). ${ }^{(4,6,9,11,16,22-29)}$

\section{Distribution Volume}

The volume of distribution (Vd) is dose dependent and varies between 5.78 and 13.5 L. (4) The following volumes of distribution of ceftriaxone were observed: 6.40-9.73 L (500 mg IV), 7.21-10.58 L (1 g IV), and 8.87-11.85 L (2 g IV). In critical patients, the pharmacokinetic parameters of ceftriaxone are altered, thus monitoring of serum concentration is recommended. ${ }^{4}$, $6,9,11,16,22-29)$

\section{Distribuição}

A área sob a curva (AUC) em doentes com a função renal normal é de $551 \pm 91 \mathrm{mcg} \times \mathrm{h} / \mathrm{ml}(500 \mathrm{mg} \mathrm{IV})$, de $1006 \pm 118 \mathrm{mcg} \times \mathrm{h} / \mathrm{ml}(1 \mathrm{~g} \mathrm{IV})$ e de $1703 \pm 203 \mathrm{mcg} \times \mathrm{h} /$ $\mathrm{ml}(2 \mathrm{~g} \mathrm{IV}) .{ }^{(24)}$ A ceftriaxona tem uma ligação às proteínas plasmáticas de $83 \%$ a $96 \%$, que é variável com a concentração. ${ }^{(4,6,9,22-29)}$

Esta cefalosporina distribui-se no: líquido sinovial (média de $14 \mathrm{mg} / \mathrm{L}$ após $1 \mathrm{~g}$ IV às 24 horas) e peritoneal (média de 15,3 a 20,1 $\mathrm{mcg} / \mathrm{ml}$ após $1 \mathrm{~g}$ IM às 12 horas), saliva e muco do trato respiratório (média de 1,54 a 2,16 $\mathrm{mcg} / \mathrm{ml}$ após $1 \mathrm{~g} \mathrm{IM} /$ dia durante 7 dias), tecido brônquico (média 11,2 $\pm 7,9 \mathrm{mcg} / \mathrm{ml}$ após $1 \mathrm{~g}$ IV às 12 horas), humor aquoso (média $2,47 \mathrm{mcg} / \mathrm{ml}$ após $2 \mathrm{~g}$ IV às 2 horas), fluido cerebrospinal (média $20 \mathrm{mcg} / \mathrm{ml}$ após $100 \mathrm{mg} / \mathrm{kg}$ às 2 horas), tecido hepático (média 130 $\mathrm{mg} / \mathrm{kg}$ após $1 \mathrm{~g}$ IV às 12 horas), pulmonar e brônquico inflamado (média 31,8 $\mathrm{mcg} / \mathrm{ml}$ após $2 \mathrm{~g}$ IV às 1 a 2 horas), ouvido médio (média $35 \mathrm{mcg} / \mathrm{ml}$ após $50 \mathrm{mg}$ / $\mathrm{kg}$ às 24,3 horas), placenta (média 19,6 a 40,6 mcg/ml) e glândula prostática (média $1 \mathrm{a} 50 \mathrm{mcg} / \mathrm{ml}$ após $2 \mathrm{~g}$ IV às 4 horas). ${ }^{(4,6,9,11,16,22-39)}$

\section{Volume de Distribuição}

O volume de distribuição (Vd) é dose dependente e varia entre 5,78 e 13,5 L. ${ }^{(4)}$ Foram observados os seguintes volumes de distribuição da ceftriaxona: $6,40-9,73 \mathrm{~L}$ (500 mg IV), 7,21-10,58 L (1 g IV), e 8,87-11,85 L (2 g IV). Nos doentes críticos, os parâmetros farmacocinéticos da ceftriaxona encontram-se alterados, pelo que se recomenda a monitorização da concentração sérica do antibiótico. ${ }^{(4,6,9,11,16,22-29)}$ 


\section{Distribution in breast milk}

Ceftriaxone passes into breast milk at low concentrations, and discontinuation of breastfeeding may be recommended. $(4,9,11,16)$ Concentration of ceftriaxone in breast milk was 3 to $4 \%$ in comparison to serum concentration in women breastfeeding after IV and IM administration of $1 \mathrm{~g}$ of ceftriaxone 3 days postpartum. ${ }^{(25)}$

\section{Placental distribution}

Since there are no controlled studies in pregnant women, and ceftriaxone crosses placenta, this antibiotic should only be used when clearly needed. It has been used successfully during the second and third trimester of pregnancy to treat severe obstetric and genitourinary infections. $(4,9,11,26)$

\section{Pediatrics}

In infants and children, the plasma protein binding is $50 \%$ lower. The $\mathrm{Vd}$ in children is $355 \mathrm{ml} / \mathrm{kg}$ compared to $160 \mathrm{ml} / \mathrm{kg}$ in adults. ${ }^{(4)}$ Fifteen minutes after the administration of $50 \mathrm{mg}$ ceftriaxone $/ \mathrm{kg}$ in 40 newborns, the mean values of the pharmacokinetic parameters were: 5.2 to 8.4 hours for the plasma half-life and from 136 to $173 \mathrm{mcg} / \mathrm{ml}$ for Cmax. ${ }^{(11,16,27)}$

\section{Metabolism}

Ceftriaxone seems to be metabolized in the gut after biliary excretion. The antibiotic is recovered in the faeces unchanged and on the form of metabolites without antimicrobial activity. ${ }^{(4,9,11,23)}$

\section{Excretion}

Ceftriaxone is excreted 3 to $4 \%$ in breast milk, $33 \%$ to $67 \%$ in the urine and $35 \%$ to $45 \%$ in the biliary way. The antibiotic is excreted unchanged by glomerular filtration. Renal clearance is $55 \mathrm{ml} / \mathrm{kg} / \mathrm{h}$ in children and $18 \mathrm{ml} / \mathrm{kg} / \mathrm{h}$ in adults. The half-life is 5.8 to 8.7 hours. In children with 1 to 8 days (weight between 1.78 and $4.36 \mathrm{~kg}$ ) the mean half - life is 19 hours. In newborns and children, the half-life is 4 to 6.5 hours. $(4,9,11,16,23)$

\section{Hepatic and Renal Impairment}

Monitoring serum ceftriaxone levels in patients with hepatic and renal impairment is recommended, and in some cases the antibiotic dose may need to be reduced (severe renal insufficiency accompanied by $80 \%$ reduction of non-renal elimination). The pharmacokinetics of ceftriaxone are minimally influenced by liver diseases. $(1,4,13)$

\section{Distribuição no leite materno}

A ceftriaxona passa para o leite materno em baixas concentrações, motivo pelo qual a interrupção poderá ser ponderada. ${ }^{(4,9,11,16)}$ Após administração IV e IM de $1 \mathrm{~g}$ de ceftriaxona 3 dias após o parto em mulheres a amamentar a concentração do antibiótico no leite materno foi de 3 a 4\% relativamente à concentração sérica. ${ }^{(25)}$

\section{Distribuição na placenta}

A ceftriaxona atravessa a placenta e como não existem estudos controlados na grávida só deve ser utilizada quando claramente necessário. Já foi utilizada com sucesso durante o segundo e o terceiro trimestre de gravidez para tratar infeções obstétricas e geniturinárias graves. ${ }^{(4,9,11,26)}$

\section{Pediatria}

Em lactentes e crianças a ligação às proteínas plasmáticas é 50\% mais baixa. O Vd em crianças é de $355 \mathrm{ml} /$ $\mathrm{kg}$ comparativamente a $160 \mathrm{ml} / \mathrm{kg}$ em adultos. ${ }^{(4)}$ Quinze minutos após a administração de $50 \mathrm{mg}$ de ceftriaxona/ $\mathrm{kg}$ em 40 recém-nascidos verificou-se que os valores médios dos parâmetros farmacocinéticos foram de: 5,2 a 8,4 horas para a semi-vida plasmática e de 136 a 173 $\mathrm{mcg} / \mathrm{ml}$ para a Cmax. ${ }^{(11,16,27)}$

\section{Metabolismo}

A ceftriaxona aparentemente é metabolizada no intestino após excreção biliar. $\mathrm{O}$ antibiótico é recuperado nas fezes inalterado e sob a forma de metabolitos sem atividade anti-microbiológica. ${ }^{(4,9,11,23)}$

\section{Excreção}

A ceftriaxona é excretada 3 a $4 \%$ no leite materno, $33 \%$ a $67 \%$ na urina e $35 \%$ a $45 \%$ por via biliar. O antibiótico é excretado inalterado por filtração glomerular. A clearance renal é de $55 \mathrm{ml} / \mathrm{kg} / \mathrm{h}$ nas crianças e de 18 $\mathrm{ml} / \mathrm{kg} / \mathrm{h}$ nos adultos. O tempo de semivida é de 5,8 a 8,7 horas. Em crianças com 1 a 8 dias de vida (peso entre 1,78 e 4,36 kg) a média da semi-vida é de $19 \mathrm{~h}$. Em recém-nascidos e crianças a semi-vida é de 4 a 6,5 horas. ${ }^{(4,9,11,16,23)}$

\section{Insuficiência Hepática e Renal}

É recomendada a monitorização da concentração sérica da ceftriaxona em doentes com insuficiência hepática e renal e em certos casos pode ser necessário reduzir a dose de antibiótico administrada (insuficiência renal grave acompanhada de redução em $80 \%$ da eliminação não renal). As doenças hepáticas influenciam a farmacocinética da ceftriaxona de forma mínima. ${ }^{(1,4,13)}$ 
Ceftriaxone is not significantly removed during hemodialysis and peritoneal dialysis. However, the elimination of ceftriaxone may be reduced in a small percentage of patients undergoing hemodialysis. In these patients is necessary to carry out serum monitoring and to proceed with dose adjustment. ${ }^{(4,9,11,22-23)}$

Dose

Adult

The usual dose for most adult infections is 1 to $2 \mathrm{~g}$ administered IM or IV in a single dose. Besides the weight, height, body surface area, age, co-morbidities or chronic medication of patients, the dose to be administered is variable with the type and severity of infection. Usually therapy should be continued for at least 2 additional days after remission of symptoms. The usual duration of treatment is 4 to 14 days and in case of infections caused by Streptococcus pyogenes should be at least 10 days. ${ }^{(4,7-9,11,16)}$ Some infections of the central nervous system may require doses of $4 \mathrm{~g}$ per day which should not be exceeded. ${ }^{(9)}$ The dose and frequency of administration are shown in Table 2.
A ceftriaxona não é removida de forma significativa durante a hemodiálise e diálise peritoneal. No entanto a eliminação da ceftriaxona pode estar reduzida numa pequena percentagem de doentes a realizarem hemodiálise e a monitorização sérica do antibiótico é necessária

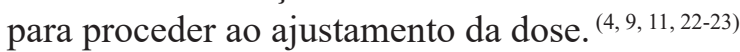

Dose

Adulto

A dose habitual para a maioria das infeções no adulto é de 1 a $2 \mathrm{~g}$ administrada por via IM ou IV em dose única. Para além do peso, altura, superfície corporal, idade, comorbilidades, ou medicação crónica dos doentes, a dose a administrar é variável com o tipo e gravidade da infeção. Normalmente a terapia deve ser continuada pelo menos por mais 2 dias após a remissão dos sintomas. A duração habitual do tratamento é de 4 a 14 dias e no caso de infeções causadas pelo Streptococcus pyogenes deve ser de pelo menos 10 dias. ${ }^{(4,7-9,11,16)}$ Algumas infeções do sistema nervoso central podem requerer doses de $4 \mathrm{~g}$ diárias as quais não devem ser excedidas. ${ }^{(9)}$ A dose e a frequência da administração estão descritas na tabela 2.

Table 2/ Tabela 2 - Dose and frequency of administration of ceftriaxone in adults (4, 9, 11, 16)/ Dose e frequência de administração da ceftriaxona $(4,9,11,16)$

\begin{tabular}{lll}
\hline & Dosage/ Dose & Frequency (h)/ \\
& & Frequência (h) \\
\hline Normal dose/ Dose normal & 1 to 2 g IM or IV & 24 \\
Uncomplicated gonorrhea/ & $250 \mathrm{mg}$ IM & Single dose/ Dose \\
Gonorreia não complicada & & única \\
Gonococcal Meningitis/ & 1 to $2 \mathrm{~g}$ IV & 12 \\
Meningite gonocócica & & \\
Surgical prophylaxis/ & $1 \mathrm{to} 2 \mathrm{~g}$ & 30 min to $2 \mathrm{~h}$ before \\
Profilaxia cirúrgica & \\
Septicemia/ Septicémia & $1 \mathrm{~g}$ IM or IV & 12 \\
Urinary Tract & 0.5 to $1 \mathrm{~g}$ IM or IV & 12 to 24 \\
Infections/Infeções do trato & \\
urinário & \\
\hline
\end{tabular}




\section{Pediatrics and Geriatrics}

As in adults, the dose and route of administration should be determined given the sensitivity of the microorganism to ceftriaxone and the type and severity of the infection. The normal duration of treatment is 4 to 14 days and should be continued for at least 2 days after remission of symptoms. In complicated infections, longer treatment periods may be required. A reduced dose may be required in elderly patients, if they are debilitated, malnourished or present a diminished renal or hepatic function. Thus, renal and hepatic function may need to be monitored in these patients. $(4,11,16)$

\section{Hepatic and Renal Impairment}

In patients with concurrent renal and hepatic impairment and in patients with severe renal impairment (e.g. dialysate patients), monitoring serum concentration of ceftriaxone and dose adjustments are recommended. In mild to moderate renal impairment, dose reductions are usually not necessary because non-renal elimination of ceftriaxone is not considerable. The half-life of ceftriaxone increases slightly from 5.8 to 8.7 hours for 11 hours in mild renal insufficiency and 15 hours in severe renal impairment. Usually ceftriaxone is not significantly removed during hemodialysis, as a result supplemental doses are not required. Thus, dose reductions of ceftriaxone on hemodialysis are dependent on the flow and filter type and on continuous flow of haemofiltration. In peritoneal dialysis, $750 \mathrm{mg}$ of ceftriaxone may be given every 12 hours. ${ }^{(4,9,11,16,22-23)}$

Dose adjustments are required in anephric (patients with $80 \%$ reduction in non-renal clearance). The halflife of ceftriaxone increased from 8 hours to 12 hours in anephric patients with normal extra-renal elimination; but in anephric patients with hepatic impairment, the half-life was 15 hours. In these patients the daily dose should not exceed $2 \mathrm{~g}$, except in situations of close

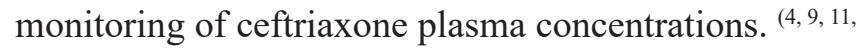
$16,22)$

\section{Overdose}

The maximum recommended dose is $4 \mathrm{~g}$ /day. Dose should not be reduced by hemodialysis or peritoneal dialysis in case of overdose. There is no specific antidote and the treatment should be symptomatic. ${ }^{(12)}$

\section{Pediatria e Geriatria}

Tal como no caso dos adultos, a dose e via de administração devem ser determinadas tendo em conta a sensibilidade do microrganismo à ceftriaxona e o tipo e a gravidade da infeção. A duração normal do tratamento é de 4 a 14 dias e deve ser continuado pelo menos por 2 dias após remissão dos sintomas. Em infeções complicadas podem ser requeridos períodos de tratamento superiores. Em doentes geriátricos debilitados, subnutridos ou com a função renal ou hepática diminuída pode ser necessário reduzir a dose. Assim, pode ser necessário monitorizar a função hepática e renal nestes doentes. ${ }^{(4,11,16)}$

\section{Insuficiência Hepática e Renal}

A monitorização da concentração sérica da ceftriaxona é recomendada em doentes com insuficiência renal e hepática simultânea, e em doentes com insuficiência renal grave (ex. doentes dialisados), bem como é necessário proceder ao respetivo ajustamento de dose sempre que necessário. Na insuficiência renal ligeira a moderada geralmente não são necessárias reduções na dose, pois a eliminação não renal da ceftriaxona não é considerável. O tempo de semi-vida da ceftriaxona aumenta de forma pouco significativa de 5,8 a 8,7 horas para 11 horas na insuficiência renal ligeira e 15 horas na insuficiência renal grave. Normalmente a ceftriaxona não é removida de forma significativa durante a hemodiálise e doses suplementares não são necessárias. Deste modo, a redução da dose da ceftriaxona na hemodiálise está dependente do fluxo e do tipo de filtro e na hemofiltração contínua do fluxo. Na diálise peritoneal pode-se administrar $750 \mathrm{mg}$ de ceftriaxona a cada 12 horas. ${ }^{(4,}$ $9,11,16,22-23)$

São necessários ajustamentos de dose em doentes anéfricos com redução em $80 \%$ da eliminação não renal. A semi-vida da ceftriaxona passou de 8 horas para 12 horas em doentes anéfricos com mecanismos normais de remoção extra-renal, no entanto nos doentes anéfricos com insuficiência hepática a semi-vida deste antibiótico foi de 15 horas. Nestes doentes a dose diária não deve exceder os $2 \mathrm{~g}$ à exceção das situações em que se faz uma monitorização estreita das concentrações plasmáticas do antibiótico. ${ }^{(4,9,11,16,22)}$

\section{Sobredosagem}

A dose máxima recomendada é de $4 \mathrm{~g} /$ dia. Em caso de sobredosagem a dose não deve ser reduzida por hemodiálise ou diálise peritoneal. Não há antídoto específico e o tratamento deve ser sintomático. ${ }^{(12)}$ 


\section{Adverse reactions}

Adverse reactions reported for ceftriaxone and the remaining cephalosporins are similar. Generally, ceftriaxone is a well-tolerated antibiotic: adverse reactions are only reported in $10 \%$ of patients and discontinuation of treatment in only $2 \%$ of all cases. ${ }^{(9)}$

Most frequent adverse reactions (incidence> 1\%): eosinophilia $(6 \%)$, diarrhea in children $(5.6 \%)$, thrombocytosis $(5.1 \%)$, increased SGOT and SGPT liver enzymes $(3 \%)$, adult diarrhea $(2.7 \%)$, hypersensitivity reactions $(2.7 \%)$, leukopenia $(2.1 \%)$, rashes $(2 \%)$, pain and inflammation with (or without) phlebitis at the site of injection (IM and IV) (1.9\%), and increased plasma creatinine $(1.2 \%)$. Uncommon adverse reactions $(<1 \%)$ : hemolytic anemia, increased azotemia, increased bilirubin and alkaline phosphatase, oral candidiasis, decreased hemoglobin hematocrit, decreased prothrombin time, formation of precipitates in the urine, nausea, vomiting, abdominal pain, flatulence, altered taste, and colitis, neutropenia, thrombocytopenia, vertigo and migraine, and increased prothrombin time. Rare adverse reactions $(<0.1 \%)$ : vaginitis (agranulocytosis, basophil, leukocytosis, lymphocytosis and monocytes), anaphylaxis, glycosuria and hematuria, jaundice, nephrolithiasis, pseudolithiasis, palpitations, bronchospasm and epistaxis, pruritus, and fever.

Also, reactions related to the time of administration were identified; the minimum time for administration of ceftriaxone $2 \mathrm{~g}$ IV is 30 minutes. Inadvertent administration of ceftriaxone over a 5 minute period resulted in prostration, tremors, diaphoresis, palpitations, and increased heart rate and blood pressure. ${ }^{(4,9,11,16,29)}$

\section{Contraindications}

Patients' hypersensitivity to ceftriaxone, or to other cephalosporin/penicillin. Increased risk of bilirubin encephalopathy in hyperbilirubinemic newborns, since ceftriaxone may displace bilirubin from serum albu$\min .{ }^{(4,9,11,16)}$

\section{Precautions}

\section{Hypersensitivity to penicillins and other allergies}

Patient's hypersensitivity reactions to cephalosporins and penicillins appear to be similar. This may be related to the $\beta$-lactam structure shared by both groups of antibiotics. ${ }^{(10)}$ Administration of ceftriaxone should be done with caution due the cross-sensitivity reactions between $\beta$-lactam antibiotics in patients' penicillin-sensitive. In
Reações adversas

As reações adversas descritas para a ceftriaxona são semelhantes às descritas para as restantes cefalosporinas. Geralmente é um antibiótico bem tolerado, as reações adversas só foram notificadas para $10 \%$ dos doentes e apenas em $2 \%$ dos casos conduziram a interrupção do tratamento. ${ }^{(9)}$

Reações adversas mais frequentes (incidência $>1 \%$ ): eosinofilia $(6 \%)$; diarreia em crianças $(5,6 \%)$; trombocitose $(5,1 \%)$; aumento das enzimas hepáticas: SGOT e SGPT (3\%); diarreia no adulto $(2,7 \%)$; reações de hipersensibilidade $(2,7 \%)$; leucopenia $(2,1 \%)$; erupções cutâneas (2\%); dor e inflamação com (ou sem) flebite no local da injecção (IM e IV) $(1,9 \%)$ e aumento da creatinina plasmática $(1,2 \%)$. Reações adversas pouco frequentes (incidência $<1 \%$ ): anemia hemolítica; aumento da azotemia ; aumento da bilirrubina e da fosfatasse alcalina; candidíase oral; diminuição do hematócrito da hemoglobina; diminuição do tempo de protrombina; formação de precipitados na urina; náuseas, vómitos, dores abdominias, flatulência, alteração do paladar e colite; neutropenia; trombocitopenia; vertigens e enxaqueca; vaginite e aumento do tempo de protrombina e reações adversas raras $(<0.1 \%)$ : agranulocitose, basófila, leucocitose, linfocitose e monócitos; anafilaxia; glicosúria e hematúria; icterícia; nefrolitíase; pseudolitíase; palpitações; broncospasmo e epistaxe; prurido; e febre.

Foram ainda identificadas reações relacionadas com o tempo de administração; o tempo mínimo para a administração de ceftriaxona $2 \mathrm{~g}$ IV é de 30 minutos. A administração inadvertida da ceftriaxona por um período de 5 minutos resultou em prostração, tremores, diaforese, palpitações e aumento do batimento cardíaco e da pressão arterial. ${ }^{(4,9,11,16,29)}$

\section{Contraindicações}

Hipersensibilidade à ceftriaxona ou outras cefalosporinas/penicilinas. Em recém-nascidos hiperbilirrubinémicos existe risco aumentado de encefalopatia por bilirrubina, pois a ceftriaxona pode deslocar a bilirrubina da albumina sérica. ${ }^{(4,9,11,16)}$

\section{Precauções}

\section{Hipersensibilidade às penicilinas e outras alergias}

As reações de hipersensibilidade das cefalosporinas parecem ser idênticas às causadas pelas penicilinas $\mathrm{e}$ isso pode estar relacionado com a estrutura $\beta$-lactâmica compartilhada por ambos os grupos de antibióticos. ${ }^{(10)}$ A administração de ceftriaxona a doentes sensíveis às penicilinas deve ser feita com precaução, porque exis- 
these patients, discontinuation of therapy should be considered. In addition to cessation of administration of medicine, treatment with epinephrine, oxygen, antihistamines and IV corticosteroids, and other clinical measures may be required to assure patients' survival. Caution is recommended, especially in patients with a history of severe drug allergies. ${ }^{(9)}$

\section{Hepatic and renal insufficiency}

In case of simultaneous hepatic and renal insufficiency or severe renal impairment (e.g. dialysis patients), ceftriaxone serum concentrations should be monitored, and dosage adjusted in order to prevent overdose. (5,30-32) $^{-1}$

Patients with hematological or immuno-compromised diseases

Although there are only a few cases reported in the literature $(<1 \%)$, immuno-compromised patients with haematological diseases are at increased risk of erythrocyte sensitization promoting onset of sudden and fatal haemolytic anemia. This sensitization may develop between 5 minutes to 34 days during treatment with ceftriaxone. Onset of symptoms is more common within minutes of administration in children. A Coomb's test is advised when starting or before each treatment with ceftriaxone. If the Coomb's test is positive, erythrocytes should be mixed with the plasma comprising complement, and ceftriaxone to check for agglutination reaction (antibiotic and antibodies form immunocomplexes on the surface of erythrocytes leading complement activation and cell destruction). Although some of the typical symptoms of hemolytic anemia are pallor, tachycardia, hypotension and dyspnea, some cases of back pain have been reported. The treatment with ceftriaxone should be stopped, and blood transfusions may be considered in case of unstable hemodynamic conditions. ${ }^{(5,30-32)}$

\section{Liver, gallbladder, biliary, or pancreas disease}

Due the possibility of formation of biliary sediment, the administration of ceftriaxone should be done with caution if patients have had a previous disease in the liver, gallbladder, biliary tract or pancreas. At the start of therapy with ceftriaxone, abdominal ultrasonography or other tests are recommended in case of colicky abdominal pain. ${ }^{(4,11,16)}$ Treatment with ceftriaxone should be discontinued whenever the patient develops signs and symptoms related to the presence of biliary sedi- tem reações de sensibilidade cruzada entre os antibióticos $\beta$-lactâmicos. Além da interrupção da terapêutica, pode ser necessário tratamento com epinefrina, oxigénio, anti-histamínicos e corticosteroides IV e outras medidas clínicas necessárias à sobrevivência do doente. Também se deve ter precaução especialmente em doentes com histórias de alergias graves a medicamentos. ${ }^{(9)}$

\section{Insuficiência hepática e renal}

Em caso de insuficiência hepática e renal simultânea ou insuficiência renal grave (ex. doentes dialisados) deve-se monitorizar as concentrações séricas de ceftriaxona e ajustar a posologia de forma a impedir situações de sobredosagem. ${ }^{(5,30-32)}$

\section{Doentes com doenças hematológicas ou imunocomprometidos}

Embora existam apenas alguns casos descritos na literatura $(<1 \%)$, doentes imunocomprometidos e com doenças hematológicas estão sujeitos a um risco acrescido de sensibilização dos eritrócitos com o aparecimento de anemia hemolítica súbita que pode ser letal. Esta sensibilização pode desenvolver-se entre 5 minutos a 34 dias durante o tratamento com a ceftriaxona. Nas crianças é mais comum o início da sintomatologia uns minutos após a sua administração. Aconselha-se um teste de Coomb's quando se inicia o tratamento e antes de cada tratamento com ceftriaxona. Se o resultado do teste de Coomb 's for positivo então deve-se misturar os eritrócitos do doente com o plasma com o complemento e a ceftriaxona para observar se há reação de aglutinação (o antibiótico e os anticorpos formam imunocomplexos na superfície dos eritrócitos que levam à activação do complemento e à destruição celular). Embora alguns dos sintomas típicos da anemia hemolítica sejam palidez, taquicardia, hipotensão e dispneia houve casos de doentes que se queixaram de uma forte dor de costas. $\mathrm{O}$ tratamento com ceftriaxona deve ser descontinuado, podendo ser consideradas transfusões sanguíneas se a condição hemodinâmica for instável. ${ }^{(5,30-32)}$

\section{Doença hepática, da vesícula biliar, das vias biliares ou do pâncreas}

Devido à possibilidade de formação de um sedimento biliar a administração de ceftriaxona deve ser feita com precaução no caso do doente ter problemas de doença prévia no fígado, vesícula biliar, trato biliar ou pâncreas. Recomenda-se a realização de ultrassonografias abdominais no início da terapêutica com ceftriaxona ou se o doente começar a ter dores abdominais do tipo cólicas, bem como outros testes ao trato biliar. ${ }^{(4,11,16)}$ $\mathrm{O}$ tratamento com a ceftriaxona deve ser interrompi- 
ment. This situation is usually reversible and transient after discontinuation of the antibiotic or the imposition of general medical measures.

\section{Diarrhea and colitis}

The occurrence of diarrhea during or after administration of ceftriaxone may be a sign of pseudomembranous colitis. Treatments with antibacterial alter the normal flora of the gastrointestinal tract and favor the exaggerated development of Clostridium. The toxin produced by Clostridium difficile is one of the primary causes of antibiotic-associated colitis. In mild cases of pseudomembranous colitis, discontinuation of the antibiotic is sufficient. In moderate to severe cases, the administration of electrolytes, protein supplements and antibiotics with antibacterial activity against Clostridium difficile (e.g., metronidazole and vancomycin) should be considered. ${ }^{(9,12)}$

\section{Risk factors for change in prothrombin time}

Renal or hepatic impairment, poor nutritional status, and prolonged antibiotic therapy are among the risk factors for change in prothrombin time. Although ceftriaxone may rarely increase prothrombin time, patients should be monitored closely for increased risk of bleeding. Exogenous administration of vitamin K $(10 \mathrm{mg}$ weekly) may be necessary. ${ }^{(4,9,12)}$

\section{Development of microbial resistance during treatment}

The use of ceftriaxone may result in overgrowth of non-susceptible microorganisms such as Candida, Enterococci, Bacteroides fragilis or Pseudomonas aeruginosa. As with other broad spectrum $\beta$-lactam antibiotics, resistance may develop during treatment (e.g., infections caused by Enterobacter and Pseudomonas aeruginosa). Periodic observation of patients during treatment with ceftriaxone is essential and periodic testing for microbial susceptibility during treatment should be considered. If a superinfection occurs during ceftriaxone treatment, appropriate therapy should be considered. ${ }^{(9,12)}$

\section{Administration outside therapeutic indications}

Administration of ceftriaxone beyond therapeutic indications is unlikely to benefit the patient and increases the risk of developing bacterial resistance. ${ }^{(12)}$ do, sempre que o doente desenvolva sinais e sintomas relacionados com a presença do sedimento biliar. Esta situação costuma ser reversível e transitória após a descontinuação do antibiótico e após a instituição de medidas gerais de carácter médico.

\section{Diarreia e colite}

A ocorrência de diarreia durante ou após a administração de ceftriaxona tem indicação para despiste de colite pseudomembranosa. $\mathrm{O}$ tratamento com antibacterianos alteram a flora normal do trato gastrointestinal e favorecem o desenvolvimento exagerado do Clostridium. A toxina produzida pelo Clostridium difficile é uma das causas primárias de colite associada a antibióticos. Em situações pouco graves de colite pseudomembranosa a descontinuação do antibiótico é suficiente. Em casos moderados a graves deve-se considerar a administração de electrólitos, suplementos proteicos e antibióticos com atividade antibacteriana contra o Clostridium difficile (ex. metronidazol e vancomicina). ${ }^{(9,12)}$

Fatores de risco para a alteração do tempo de protrombina

Entre os fatores de risco para a alteração do tempo de protrombina temos o compromisso renal ou hepático, o estado nutricional fraco e a terapêutica prolongada com antibióticos. Ainda que raramente a ceftriaxona pode aumentar o tempo de protrombina. Assim, estes doentes devem ser mais atentamente monitorizados para o aumento do risco de hemorragia e em caso de ser necessário proceder à administração exógena de vitamina K (10 mg semanalmente). ${ }^{(4,9,12)}$

\section{Desenvolvimento de resistências microbianas durante o tratamento}

A utilização de ceftriaxona pode resultar no supercrescimento de microrganismos não suscetíveis como a Candida, Enterococci, Bacteroides fragilis ou Pseudomonas aeruginosa. Tal como com outros antibióticos $\beta$-lactâmicos de largo espectro podem desenvolver-se resistências durante o tratamento (ex. infeções causadas por Enterobacter e Pseudomonas aeruginosa). A observação periódica do doente durante o tratamento com ceftriaxona é essencial e deve-se ponderar a realização de testes periódicos à susceptibilidade microbiana durante o tratamento. Caso ocorra uma superinfeção durante o tratamento ceftriaxona, deve ser considerada a instituição de terapêutica apropriada. ${ }^{(9,12)}$

\section{Administração fora das indicações terapêuticas}

A administração de ceftriaxona fora das indicações terapêuticas é pouco provável que beneficie o doente e aumenta o risco de se desenvolverem resistências bacterianas. ${ }^{(12)}$ 


\section{Long-term treatments}

Severe and reversible neutropenia has been reported with high doses of ceftriaxone in prolonged treatment. These patients are advised to monitor white blood cells. $(4,11,16)$

\section{Interference with laboratory tests}

Ceftriaxone may interfere with urine glucose determination methods involving cupric sulfate. Glucose oxidase method is not affected. ${ }^{(3,4,9,12)}$

\section{Cephalosporins consumed in community per Portuguese} districts in 2015

In 2015, the average consumption of antibiotics in outpatient settings was 21.25 DHD in Portugal according to data from the European Center for Disease Prevention and Control (ECDC). The districts of Lisbon, Coimbra, Portalegre, Porto and Leiria showed consumption above the national average in 2015 . The consumption of Cephalosporins of $1^{\text {st }}, 2^{\text {nd }}$ and $3^{\text {rd }}$ generation by DHD per Portuguese districts is presented in Figures 2 to 4 (2015 data). ${ }^{(3)}$

\section{Tratamentos por períodos prolongados}

Neutropenia grave e reversível foi reportada com doses elevadas de ceftriaxona em tratamentos por períodos prolongados. Nesses doentes é aconselhada a monitorização das células brancas sanguíneas. ${ }^{(4,11,16)}$

\section{Interferência com os testes laboratoriais}

Pode interferir com os métodos de determinação da glucose urinária que utilizem o sulfato cúprico. Todas as determinações realizadas pelo método da glucose oxidase não são afetadas. ${ }^{(3,4,9,12)}$

Perfil de cefalosporinas consumidas em ambulatório em Portugal por distrito no ano de 2015

No ano 2015, a média de consumo de antibióticos em meio ambulatório foi de 21,25 DHD em Portugal de acordo com os dados do Centro Europeu de Prevenção e Controlo de Doenças (ECDC). Os distritos de Lisboa, Coimbra, Portalegre, Porto e Leiria apresentaram consumos acima da média nacional nesse ano. A seguir apresenta-se respetivamente, o consumo de cefalosporinas de $1^{\mathrm{a}}, 2^{\mathrm{a}}$, e $3^{\mathrm{a}}$ geração por DDH e Distrito em Portugal no ano de 2015 (Figuras 2 a 4). ${ }^{(3)}$

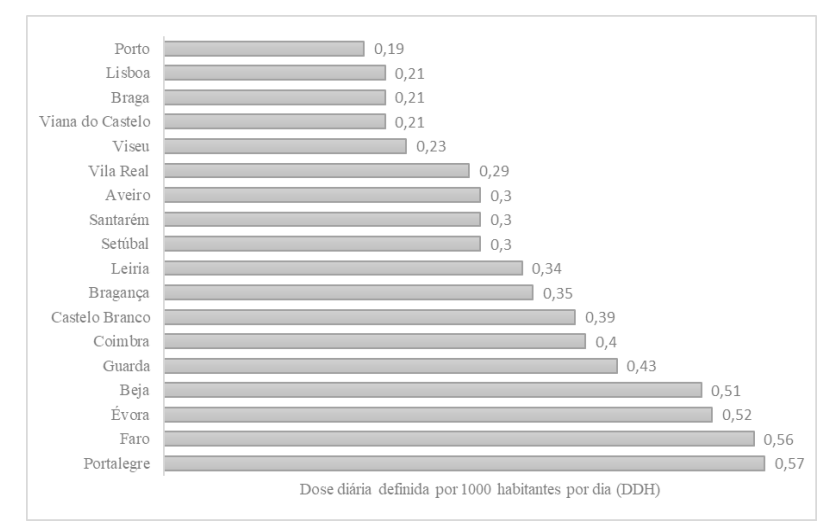

Figure 2/ Figura 2 - Use of 1st generation cephalosporins per district in 2015/Utilização de cefalosporinas de $1^{\mathrm{a}}$ geração por distrito em 2015 
The Portuguese districts with higher and lower consumption of $1^{\text {st }}$ generation cephalosporins were respectively Portalegre (0.57 DHD) and Porto (0.19 DHD). The consumption in Porto was 3 times inferior than Portalegre (Figure 3).

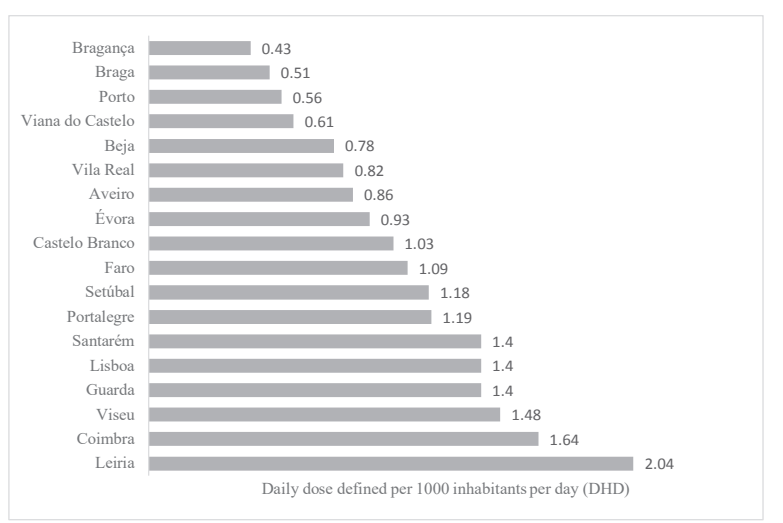

Os distritos com maior e menor consumo de cefalosporinas de $1^{\text {a }}$ Geração em Portugal foram, respetivamente, Portalegre (0,57 DHD) e Porto (0,19 DHD). Ou seja, o Porto teve um consumo 3 vezes inferior a Portalegre (Figura 3).

Figure 3/ Figura 3 - Use of 2nd generation cephalosporins per district in 2015/ Utilização de cefalosporinas de $2^{\mathrm{a}}$ geração por distrito em 2015

The Portuguese districts with higher and lower consumption of $2^{\text {nd }}$ generation cephalosporins were respectively Lisbon (2.04 DHD) and Bragança (0.43 DHD). The consumption in Bragança was 4.7 times lower than Lisbon.
Os distritos com maior e menor consumo de cefalosporinas de $2^{\mathrm{a}}$ Geração em Portugal foram, respetivamente, Lisboa (2,04 DHD) e Bragança (0,43 DHD). Ou seja, Bragança teve um consumo 4,7 vezes inferior a Lisboa.
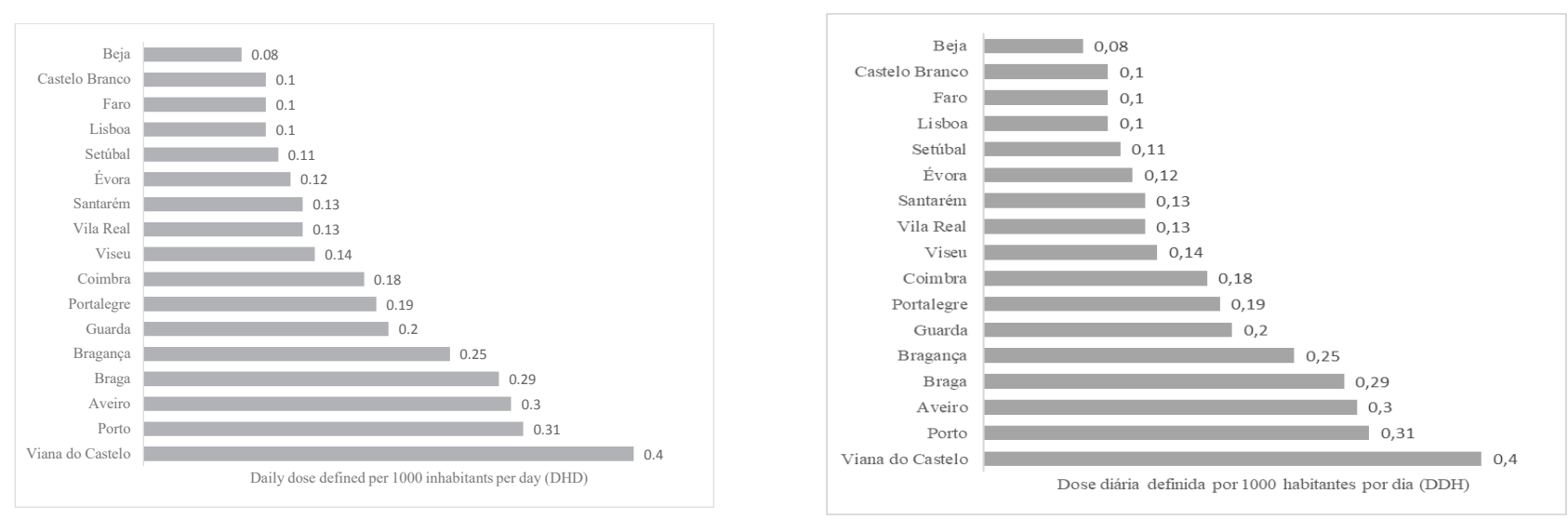

Figure 4/ Figura 4 - Use of 3th generation cephalosporins per district in 2015/ Utilização de cefalosporinas de $3^{\mathrm{a}}$ geração por distrito em 2015 
The Portugese districts with higher and lower consumption of $3^{\text {rd }}$ generation cephalosporins were respectively Viana do Castelo (0.4 DHD) and Beja (0.08 DHD). The consumption in Beja was 5 times lower than Viana do Castelo.

Safety alerts of ceftriaxone issued by the National and European agencies of medicines

Two safety informative documents on ceftriaxone (n. ${ }^{\circ}$ 011/CA 2007 and 202/CD 2009 of INFARMED, I,P,) were identified. ${ }^{(33,34)}$ These documents were based on the benefit risk assessment of the European Medicines Agency. In both documents, updates on the summary of the medicinal product's characteristics were recommended, namely: inclusion of warnings regarding concomitant calcium administration (risk of precipitation of ceftriaxone-calcium salt in patients less than 28 days old; fatal cases of ceftriaxone-calcium salt precipitation in the lungs and kidneys of preterm infants have occurred), contraindications in preterm infants and neonates (up to 28 days old) with jaundice, hypoalbuminemia, or acidosis (ceftriaxone has the potential to displace bilirubin from its binding to serum albumin, which may lead to encephalopathy), and recommendations to avoid concurrent administration of calcium and ceftriaxone infusions in patients over 28 days old, even using different infusion routes. Also included in summary of product characteristics was that ceftriaxone may precipitate in the gallbladder and kidneys, being detectable later as shadows on ultrasound images.

\section{Discussion and conclusion}

Ceftriaxone has activity against several Gram-positive and Gram-negative bacteria. This antibiotic is used to treat various types of infections, including pneumonia, septicemia, and meningitis, which can be life-threatening. Ceftriaxone is administered by intramuscular injection or by intravenous infusion and, except for some contraindications, may be administered in all age groups, which supports the clinical relevance of this antibiotic. Ceftriaxone maintains a favorable efficacy and safety profile, which is reinforced by the fact that the number of alerts from medicine agencies on ceftriaxone are limited. Positively, Portugal registered a global consumption of antibiotics (21.25 DHD in 2015 vs. 21.6 DHD in 2016) below the average of the European Union (22.4 DHD in 2015 vs. 21.9 DHD in 2016). ${ }^{(3,35)}$ Nevertheless, the Portuguese average is still considered high, with a possible impact on the development of bacterial resistances. For instance, the use of antibiotics,
Os distritos com maior e menor consumo de cefalosporinas de $3^{\mathrm{a}}$ Geração em Portugal foram, respetivamente, Viana do Castelo (0,4 DHD) e Beja (0,08 DHD). Ou seja, Beja teve um consumo 5 vezes inferior a Viana do Castelo.

Alertas de segurança da ceftriaxona emitidos pelas agências: Nacional e Europeia do medicamento

Foram detetadas duas Circulares informativas de segurança Sobre a ceftriaxona (Circulares informativa $n .^{\circ}$ 011/CA de 2007 e 202/CD de 2009 do INFARMED, I.P.). ${ }^{(33,34)}$ As mesmas foram baseadas na avaliação risco benefício da Agência Europeia do Medicamento. Em ambas as circulares foram recomendadas atualizações no resumo das características do medicamento, nomeadamente: inclusão das advertências relativas à administração concomitante com cálcio (risco de precipitação do sal ceftriaxona-cálcio em doentes com menos de 28 dias; verificaram-se casos fatais de precipitações de sais de ceftriaxona-cálcio nos pulmões e rins de recém-nascidos prematuros), contraindicações em prematuros e recém-nascidos (até aos 28 dias) com icterícia, hipoalbuminemia ou acidose (a ceftriaxona tem potencial para deslocar a bilirrubina da sua ligação à albumina sérica, o que pode levar a encefalopatia bilirrubínica), e recomendações para se evitar a administração simultânea de infusões de cálcio e ceftriaxona em doentes com mais de 28 dias, mesmo usando vias de perfusão diferentes. Além disso foi incluída a informação, que a ceftriaxona pode precipitar na vesícula biliar e nos rins, sendo posteriormente detetável como sombras nos ultrassons.

\section{Discussão e conclusão}

A ceftriaxona tem atividade contra diversas bactérias Gram-positivas e Gram-negativas. Este antibiótico é utilizado para tratar vários tipos de infeções, incluindo pneumonia, septicemia e meningite, que podem ser potencialmente fatais. É administrada por injeção intramuscular ou por perfusão intravenosa e, excetuando alguma contraindicação pode ser administrado em todos os grupos etários, o que reforça a sua relevância clínica no leque de antibióticos utilizados. A ceftriaxona mantém um perfil de eficácia e segurança favorável, o que é reforçado pelo facto de o número de alertas de segurança das Autoridades do Medicamento sobre este antibiótico ser limitado. Positivamente, Portugal registou um consumo global de antibióticos (21.25 DHD em 2015 vs. 21.6 DHD em 2016) abaixo da média da União Europeia (22.4 DHD em 2015 vs. 21.9 DHD em 2016). ${ }^{(3,}$ ${ }^{35)}$ Não obstante, a média Portuguesa ainda é considerada elevada, com possível impacto ao nível do desen- 
including cephalosporins was much higher in Portugal than that of countries such as the Netherlands, Hungary and Poland according to the latest data published by ECDC in 2015. (1,3,35) $^{2}$

It is possible to hypothesize that cephalosporins, including ceftriaxone, may be prescribed outside the scope of their therapeutic indications, since noticeable variations in their consumption were detected between some Portuguese districts. In this context, it is imperative to monitor the development of bacterial resistances.

\section{Suggestions for future work}

Qualitative analysis is suggested to check the motives that led physicians to prescribe cephalosporins, and to confirm the fulfilment of therapeutic indications. The development of a national form is also recommended, in which prescribers qualitatively justify the prescription of antibiotics.

\section{Conflict of interest}

The authors declare that there is no financial or personal relationship that can be understood as representing a potential conflict of interest. volvimento de resistências bacterianas. Por exemplo, a utilização de antibióticos, incluindo cefalosporinas foi muito superior à de Países como a Holanda, Hungria e Polónia de acordo com os dados mais recentes publicados pelo ECDC em 2016. ${ }^{(1,3,35)}$

É possível colocar a hipótese que as cefalosporinas, incluindo a ceftriaxona possam estar a ser prescritas fora do âmbito das suas indicações terapêuticas, pois verificaram-se variações notórias no seu consumo entre alguns distritos Portugueses. Neste âmbito, é imprescindível vigiar o desenvolvimento de resistências bacterianas.

\section{Sugestões de trabalho futuro}

Análise qualitativa dos motivos que levam à prescrição de cefalosporinas de modo a vigiar o cumprimento das indicações terapêuticas. Desenvolver um formulário Nacional, em que todos os prescritores tenham de justificar qualitativamente a dispensa de antibióticos.

\section{Conflito de interesses}

Os autores declaram que não existe uma relação financeira ou pessoal que possa ser entendida como representando um potencial conflito de interesses. 


\section{References/Referências}

1) INFARMED, I.P. (2018). Consumo de antibióticos. http://www.infarmed.pt/web/infarmed/entidades/medicamentos-uso-humano/monitorizacao-mercado/ benchmarking/benchmarking-hospitalar/antibioticos (9-8-2018)

2) Cals JWL, Butler CC, Hopstaken RM, et al. Effect of point of care testing for $\mathrm{C}$ reactive protein and training in communication skills on antibiotic use in lower respiratory tract infections: cluster randomised trial. BMJ 2009; 5:338-b1374.

3) INFARMED, I.P. (2016). Antibióticos em Portugal. http://www.infarmed.pt/documents/15786/2219894/Antibi\%C3\%B3ticos+Espectro+largo+e+estreito+em+ambulat\%C3\%B3rio+\%282014-2016\%29/5817b82c-345c-4e7d-aea8-4b4072937a77?version=1.1 (9-8-2018)

4) Australian Register of Therapeutic Goods. Product Information: Ceftriaxone Sandoz $1 \mathrm{~g} / 2 \mathrm{~g}$ powder for injection.2016.

5) Bijie H, Kulpradist S, Manalaysay M,, et al. In vitro activity, pharmacokinetics, clinical efficacy, safety and pharmacoeconomics of ceftriaxone compared with third and fourth generation cephalosporins: review. J Chemother 2005; 17(1):3-24.

6) Moskovitz LB. Clinical Adverse Effects during Ceftriaxone Therapy. The American Journal of Medicine 1984; 77: 84-8.

7) Schleibinger M, Steinbach CL, Töpper C, et al. Protein binding characteristics and pharmacokinetics of ceftriaxone in intensive care unit patients. Br J Clin Pharmacol. 2015; 80(3):525-33.

8) Epstein SJ, Hasselquist MS, Simon LG. Efficacy of Ceftriaxone in Serious Bacterial Infections. Antimicrobial Agents and Chemotherapy 1982; 21(3): 402-6.

9) American Society of Health-Sytem Pharmacists. American Hospital Formulary Drug information 1998: Ceftriaxone. 40th edition, USA, 1998. ISBN: 1-879907-6-3.

10) Gilman, Alfred Goodman (ed). As Bases Farmacológicas da Terapêutica: Antimicrobianos. 10th edition, Lisbon, Mc Graw Hill, 1987. ISBN: 85-86804$28-2$.

11) Martindale the Extra Pharmacopeia. Antibacterial Agents: Ceftriaxone. 31th edition, London, Royal Pharmaceutical Society, 1996. ISBN: 0-85369-342-0.

12) Summary of Product Characteristics. Rocephin. ${ }^{\circledR}$ Approved by INFARMED, I.P., 2015

13) Dancer SJ.The problem with cephalosporins, Journal of Antimicrobial Chemotherapy 2001; 48:463-478.

14) Garret J, Osswald W. (Coord). Terapêutica Medicamentosa e suas Bases Farmacológicas: Cefalosporinas. 2nd Edition, Lisbon, Porto Editora, 1987.

15) World Health Organization. (2001)!. WHO model prescribing information : drugs used in bacterial infections. Geneva : World Health Organization. http:// www.who.int/iris/handle/10665/42372

16) Australian Register of Therapeutic Goods. Product Information: Ceftriaxone Alphapharm. 2016.

17) Lefebvre B, Martin I, Demczuk W, et al. Ceftriaxone-Resistant Neisseria gonorrhoeae, Canada, 2017. Emerg Infect Dis. 2018; 24:381-383.

18) Glauser MP, Baumgartner J. Pharmacokinetic and susceptibility studies of Ceftriaxone. Eur J Clin Microbiol 1983; 2(5): 501-4.

19) Just HM, Beckert A, Bater M., et al. Combination Effect of Ceftriaxone with four aminoglycosides on Nonfermenting Gram-Negative Bacteria. Chemotherapy $1982 ; 28: 397-401$

20) Cottagnoud P, Acosta F, Cottagnoud M, et al. Synergy between Trovafloxacin and Ceftriaxone against Penicillin Resistant Pneumococci in the Rabbit Meningitis Model and In Vitro. Antimicrobial Agents and Chemotherapy 2000; 44(8): 2179-81.

21) Trindade MT, Salgado H. A Critical Review of Analytical Methods for Determination of Ceftriaxone Sodium, Critical Reviews in Analytical Chemistry 2018; 48: 95-101.

22) Meenks SD, Foudraine NA, Janssen PKC, et al. Pharmacokinetics and dose individualization of ceftriaxone in a hepatically-impaired, critically-ill patient receiving continuous venovenous hemofiltration. Int J Clin Pharmacol Ther. 2018; 56: 148-150.

23) Patel HI, Sugihara J, Weinfeld R, et al. Ceftriaxone Pharmacokinetics in Patients with Various Degrees of Renal Impairment. Antimicrobial Agents and Chemotherapy 1984; 25(4): 438-42.

24) Dailly E, Verdier MC, Deslandes G, et al. Level of evidence for therapeutic drug monitoring of ceftriaxone. Therapie 2012;67(2): 145-9.

25) van Wattum JJ, Leferink TM, Wilffert B, et al. Antibiotics and lactation: An overview of relative infant doses and a systematic assessment of clinical studies. Basic Clin Pharmacol Toxicol. 2018, 1-13

26) Bourget P, Fernandez H, Quinquis V, et al. Pharmacokinetics and Protein Binding of Ceftriaxone during Pregnancy. Antimicrobial Agents and Chemotherapy $1993 ; 37(1): 54-9$.

27) Du Y, Wang Y, Xie J, et al. Ceftriaxone associated biliary pseudolithiasis in a child: a case report and review of the literature. Int J Clin Exp Med 2018;11(7): 7502-7509.

28) Young LY, Kodda-Kimble MA (ed). Applied Therapeutics, The Clinical Use of Drugs: Dosing of Drugs in Renal Failure. 6th edition, USA, 1995, ISBN: 0-915486-23-7.

29) Lossos IS, Lossos A. Hazards of rapid administration of Ceftriaxone. The Annals of Pharmacotherapy 1994; 28:807-8.

30) Leicht HB, Weinig E, Mayer B, Viebahn J, Geier A, Rau M. Ceftriaxone-induced hemolytic anemia with severe renal failure: a case report and review of literature. BMC Pharmacol Toxicol. 2018;19(1):67.

31) Jinmiao Lu, Qin Li, Xiaoxia Li, et al. A Fatal Case Report of Ceftriaxone-induced Hemolytic Anemia and Literature Review in Pediatrics. International Journal of Pharmacology 2018; 14: 896-900.

32) Mattis L, Saavedra MJ, Shan Hua, et al. Life-Threatening Ceftriaxone-Induced Immune Hemolytic Anemia in a Child with Crohn's Disease. Clinical Pediatrics 2004; 43: 175-78.

33) INFARMED, I.P. (2007). Circular informativa N. ${ }^{\circ}$ 011/CA: Informação de segurança da Ceftriaxona. http://www.infarmed.pt/documents/15786/1091622/8672458.PDF/eb016086-9bd3-4ace-86da-286203ec1468?version=1.0 (9-8-2018).

34) INFARMED, I.P. (2009). Circular informativa N. ${ }^{\circ}$ 202/CD: Informação de segurança da Ceftriaxona. http://www.infarmed.pt/documents/15786/1092759/8665842.PDF/075aa0bc-797e-4c0f-8177-b92bd03826bf?version=1.0 (9-8-2018).

35) ECDC. Annual Epidemiological Report for 2016 Antimicrobial consumption. https://ecdc.europa.eu/sites/portal/files/documents/AER_for_2016-AMC. $\operatorname{pdf}(9-11-2018)$. 